\title{
O CONTROLE DO PODER
}

\author{
DANIELA COURTES LUTZKY*
}

RESUMO: Intenta-se com este trabalho analisar o controle do poder. Para começar este estudo, entretanto, faz-se necessária uma explanação sintética sobre o que é o poder e quando ocorre o abuso deste poder, problema de difícil solução. Somente depois dessa visão é que passamos a analisar a separação dos poderes e a democracia como formas de controle do abuso do poder, bem como a contribuição de Montesquieu sobre a teoria da separação dos poderes que, por sua vez, diferencia-se dos checks and balances, instituto último a ser apreciado na pesquisa em tela.

PALAVRAS-CHAVE: Controle do Poder; Separação dos Poderes; Checks and Balances.

ABSTRACT: The control of the power intends by this work to analysis. To begin this study, therefore, a synthetic explanation is made necessary on what it is the power and when there takes place the abuse of this power, problem of difficult matter. Only after this vision and we start to analysis the separation of the powers and the democracy like the forms of control of the abuse of the power, as well as the contribution of Montesquieu on the theory of the separation of the powers that, for his time, differentiates of the checks and balances, last institute to be appreciated in the inquiry in screen.

KEYWORDS: Control of the Power; Separation of the Powers; Checks and Balances.

SUMÁRIO: 1. A separação dos poderes, a democracia e o checks and balances; 1.1 Da separação dos poderes e da teoria da democracia também como oposição ao estado absoluto; 1.2 A separação dos poderes por Montesquieu e a doutrina dos checks and balances; 2. Considerações Finais; 3. Referências.

SUMMARY: 1 . The separation of powers, democracy and the checks and balances; 1.1 Of the separation of powers and of the theory of democracy also as opposition to the absolute State; 1.2 The separation of powers by Montesquieu and the checks and balances doctrine; 2. Final Remarks; 3. References.

\section{A SEPARAÇÃO DOS PODERES, A DEMOCRACIA E O CHECKS AND BALANCES \\ 1.1 Da Separação dos Poderes e da Teoria da Democracia também como oposição ao Estado Absoluto \\ Como começamos o presente trabalho trazendo o conceito e o alcance do que é o poder, temos que lembrar, agora, que o poder é importante e tem que ser estudado e}

Artigo recebido em 10.06.2009 e aprovado para publicação pelo Conselho Editorial em 14.10.2009.

* Doutoranda em Direito do Estado pela Pontifícia Universidade Católica do Rio Grande do Sul, Professora da mesma instituição na Graduação e no Pós; Professora do Centro Universitário Ritter dos Reis; Professora do Pós-graduação da UFRGS em Direito Privado; Professora da Escola da Defensoria Pública; Professora de diversos cursos preparatórios para prova da OAB e concursos e Advogada. 
compreendido se almejamos que o Estado de Direito ${ }^{1}$ se torne uma realidade, ou seja, se pretendemos que o poder político seja disciplinado e venha a ser exercido de acordo com a legalidade de modo a permitir que o povo tenha os seus direitos protegidos por meio dos mecanismos adotados para o controle do poder político.

O Estado Moderno precisou da separação dos poderes em determinado momento de sua evolução por motivos políticos: passagem do absolutismo monárquico absorvente para o liberalismo constitucionalista democratizante. Separar entre si as partes ativas do governo seria um corretivo ao poder absoluto, e portanto, ao tipo de Estado que o liberalismo combateu e que precisou ser combatido para que se chegasse ao constitucionalismo e ao Estado de Direito. A questão consistiu em organizar o funcionamento dos órgãos políticos fundamentais, para que a existência de um governo não comprometesse o grau de liberdade social alcançado ${ }^{2}$.

Igualmente nesse sentido são as palavras de Norberto Bobbio ${ }^{3}$ :

O problema fundamental do Estado constitucional moderno, que se desenvolve como antítese do Estado absoluto, é o problema dos limites do poder estatal. Grande parte das teorias elaboradas no curso dos séculos e que levaram à formação do Estado liberal e democrático estão inspiradas em uma idéia fundamental: a de estabelecer limites ao poder do Estado. O Estado, entendido como a forma suprema de organização de uma comunidade humana, traz consigo, já a partir das suas próprias origens, a tendência para colocar-se como poder absoluto, isto é, como poder que não reconhece limites, uma vez que não reconhece acima de si mesmo nenhum outro poder superior. Este poder do Estado foi chamado de soberania, e a definição tradicional de soberania, que de adequa perfeitamente à supremacia do Estado sobre todos os outros ordenamentos da vida social, é a seguinte: potestas superiorem non recognoscens. Portanto, o Estado absoluto coloca-se como a encarnação mais perfeita da soberania entendida como poder que não reconhece ninguém superior.

O Estado absoluto nasce da dissolução da sociedade medieval que era de caráter eminentemente pluralista. Dizendo que a sociedade medieval tinha um caráter pluralista, queremos afirmar que o direito segundo o qual estava regulada originava-se de diferentes fontes de produção jurídica, e estava organizado em

\footnotetext{
${ }^{1}$ Sobre o tema sugere-se "O Estado de Direito e seus limites", de VIEIRA, Oscar Vilhena. In ZIMERMAN, David e COLTRO, Antônio (orgs). Aspectos psicológicos na prática jurídica. São Paulo: Millenium, 2002, p. 383-396.

${ }^{2}$ SALDANHA, Nélson. O Estado Moderno e a Separação de Poderes. São Paulo: Saraiva, 1987, p. 115. O mesmo autor às páginas 116 refere: "A relação entre a separação de poderes e o problema genérico do controle dos atos governamentais é bastante óbvia e se acha na base da universalização do tema. Separar os poderes era algo que se contrapunha, no entendimento clássico, à concentração; de sorte que a alternativa entre separar e não separar pareceu, a certos autores, equivalente a uma opção entre o Estado absoluto e o Estado liberal (ou liberal-democrático). A opção pelo Estado democrático repousaria sobre a posse, por parte do povo, da soberania e dos poderes fundamentais; mas seria preciso organizar as funções e os órgãos, de modo que aquela posse pudesse ser de fato exercida, ao menos indiretamente. A opção pelo Estado liberal repousaria sobre um esquema que mantivesse a ação governamental dentro do mínimo necessário, impedindo-a de asfixiar as liberdades (inclusive as liberdades sociais, culturais e econômicas); mas para isso seria necessário dar ao governo limitações internas e externas".

${ }^{3}$ BOBBIO, Norberto. Direito e Estado no Pensamento de Emanuel Kant. Trad. Alfredo Fait. Brasília: Editora Universidade de Brasília, 1997, p. 11-12.
} 
diversos ordenamentos jurídicos. No que diz respeito às fontes, operavam na sociedade medieval ao mesmo tempo, ainda que com diferente eficácia, os vários fatos ou atos normativos que, numa teoria geral das fontes, são considerados como possíveis fatos constitutivos de normatividade jurídica, quer dizer o costume (direito consuetudinário), a vontade da classe política que detém o poder supremo (direito legislativo), a tradição doutrinária (direito científico), a atividade das cortes de justiça (direito jurisprudencial). Com relação à pluralidade dos ordenamentos, pode-se dizer em geral que existiam ordenamentos jurídicos originários e autônomos seja acima do regnum, isto é, a Igreja e o Império, seja abaixo, como os feudos, as comunas, as corporações. Em uma sociedade na qual não existe um poder único e unitário, não existindo portanto um critério único de avaliação jurídica, os limites do poder estão incluídos na sua própria estrutura, segundo o equilíbrio recíproco que os vários poderes produzem com a sua concórdia discors e discórdia concors.

Qualquer dos sistemas de controle é importante para que exista a proteção dos valores e direitos que, pela própria natureza do poder, tendem a ser desrespeitados uma vez que aquele que detém o poder sempre quer mais poder, além de, por vezes ainda, tentar impor arbitrariamente a sua vontade sem levar em conta as conseqüências dos atos "tiranos".

A restrição do exercício do poder político prevista em lei (lato sensu) é o primeiro passo para o controle do poder, mas, no entanto, não é o suficiente para um controle efetivo, podendo, como já referido, por exemplo, também haver a responsabilização dos funcionários que abusem do poder que dispõem.

A ainda que relativa, separação de funções entre os órgãos estatais, tem por objetivo justamente o equilíbrio no exercício das respectivas funções, pois permite relações de coordenação e cooperação entre os órgãos. É essa interdependência de funções que possibilita o controle dentro da estrutura tripartida do exercício do poder.

A Constituição Federal de 1988 consagrou o princípio da separação de poderes no seu art. $2^{\text {o: }}$ "São Poderes da União, independentes e harmônicos entre si, o Legislativo, o Executivo e o Judiciário". À Constituição, portanto, incumbe prever e regular o funcionamento do controle do poder, sendo que o respeito à legalidade é uma garantia de que o povo não será tratado como escravo, mas, sim, como cidadão, além de ser elemento essencial da democracia.

Para Nelson Saldanha4: "salta à vista o fato de que, nas Constituições de hoje - e sobretudo na prática política - a realidade do problema dos poderes não corresponde, senão em certa medida, ao esquema separativo engendrado pelos clássicos”.

Anna Cândida da Cunha Ferraz $z^{5}$ anota que:

\footnotetext{
${ }^{4}$ SALDANHA, Nélson. O Estado Moderno e a Separação de Poderes. São Paulo: Saraiva, 1987, p. 122. O mesmo autor às páginas 113 diz que: "O que a divisão ou separação entre funções governamentais garante é, em primeiro termo, que se evite a concentração de atribuições, ou seja, o governo autocrático”. ${ }^{5}$ FERRAZ, Anna Cândida da Cunha apud TAVARES, André Ramos. Curso de Direito Constitucional. São Paulo: Saraiva, 2003, p. 865.
} 
No desdobramento constitucional do esquema de poderes, haverá um mínimo e um máximo de independência de cada órgão de poder, sob pena de se desfigurar a separação, e haverá, também, um número mínimo e um máximo de instrumentos que favoreçam o exercício harmônico dos poderes, sob pena de, inexistindo limites, um poder se sobrepor ao outro poder, ao invés de, entre eles, se formar uma atuação'de concerto'”.

Bem lembra Fernando Lima ${ }^{6}$ que:

Quando se fala em separação dos poderes ${ }^{7}$, é sempre necessário ter em mente os seus objetivos, ou seja: a soberania popular, a eficácia constitucional e a proteção dos direitos fundamentais. É preciso fazer esta pergunta: para que serve a separação dos poderes? Em primeiro lugar, ela deve tornar realidade a democracia, ou a promessa do governo popular $\left(\mathrm{CF} / 88\right.$, art. $1^{\circ} \mathrm{e}$ parágrafo único). Em segundo lugar, a Constituição deve ser respeitada pelos governantes e pelos governados e deve ser efetivada pelos órgãos competentes, em especial pela jurisdição constitucional. De nada servem as leis e a Constituição, por mais democráticas que possam parecer, se elas não puderem ser efetivadas de modo imparcial. O terceiro objetivo da separação dos poderes é a proteção dos direitos fundamentais, sem o que os princípios democráticos e a regra da maioria poderão se tornar, com facilidade, instrumentos da tirania.

A doutrina da separação dos poderes ${ }^{8}$ diz respeito a um equilíbrio entre órgãos independentes quanto à formação e à subsistência, funcionalmente diferenciados e dotados de específicos mecanismos e dispositivos constitucionais destinados à fiscalização recíproca dos respectivos atos. Em um primeiro momento passaram para

\footnotetext{
${ }^{6}$ LIMA, Fernando Machado da Silva. Jurisdição Constitucional e Controle do Poder. Porto Alegre: Sérgio Antônio Fabris Ed., 2005, p. 39.

7 "No Brasil, a prática política tem levado, talvez sob a influência de nossa herança ibérica, ao excessivo fortalecimento do Poder Executivo, demonstrando a ineficácia de nossos controles institucionais. Nossos últimos Presidentes, aproveitando-se da omissão do STF, têm exercido quase que discricionariamente o poder legiferante, invadindo as atribuições do Congresso Nacional, pela excessiva utilização e reedição de medidas provisórias.” (...) “O normal, no Brasil, é que os Executivos, federais, estaduais ou municipais, frequentemente aliados aos órgãos legislativos, sejam sempre tentados a aprovar normas inconstitucionais, sob os mais diversos pretextos, que vão da urgência até à ameaça de ingovernabilidade, atingindo assim com essa legislação os direitos do povo, assegurados pela Constituição. Apenas para exemplificar, pode ser citado, no plano federal, o abuso das medidas provisórias, que recentemente o Congresso tentou limitar, através da Emenda Constitucional n 32/01. O abuso se deve, essencialmente, à ineficácia de nossa jurisdição constitucional, porque o Supremo decidiu que eram constitucionais as reedições de medidas provisórias e disse também que não poderia apreciar a questão dos requisitos da relevância e urgência, exigidos pela Constituição Federal. Em decorrência, os nossos Presidentes, desde o início da última década do século passado, têm legislado indiscriminadamente, sem atentarem aos limites constitucionais da relevância e da urgência. Em certas matérias, chegamos ao absurdo de ter medidas provisórias que vêm sendo reeditadas há sete anos. Como justificar, nesses casos extremos, o requisito da urgência? Para que serviria o Congresso Nacional, afinal de Contas, se o Presidente da República pode legislar sozinho, com muito maior eficiência?” LIMA, Fernando Machado da Silva. Jurisdição Constitucional e Controle do Poder. Porto Alegre: Sérgio Antônio Fabris Ed., 2005, p. 40; 229-230.

${ }^{8}$ Acerca da história da separação dos poderes sugere-se PIÇARRA, Nuno. A Separação dos Poderes como Doutrina e Princípio Constitucional. Um contributo para o estudo das suas origens e evolução. Coimbra: Coimbra Editora Limitada, 1989.
} 
o primeiro plano as relações entre o órgão legislativo e o executivo; ou seja, foram analisadas e ressaltadas as relações entre o Parlamento (incluindo as relações entre as duas Câmaras) e o Rei, tidos como órgãos independentes ou separados. Só mais tarde o Judiciário veio a ter sua importância na doutrina da separação dos poderes.

Ainda nesse viés o impeachment é tido como um expediente essencial de que dispõe o Parlamento para efeitos de controle dos atos dos ministros do rei; isto é, o Parlamento não executa mas controla o exercício da função executiva. Há, de outra banda, o poder de veto que é do Rei (negative voice), demonstrando a oposição do Rei a um ato legislativo autônomo e perfeito, de exclusiva autoria do Parlamento. Vemos, portanto, que o Rei não participa da legislação mas a controla, podendo, inclusive, impedi-la de entrar em vigor. Na verdade, nem o impeachment nem o veto têm natureza legislativa ou executiva, antes disso exprimem, basicamente, um poder de controle. O que não se poder negar, por óbvio, é um nexo entre o veto e a legalidade monárquica do Rei, e outro nexo entre o impeachment e a legitimidade democrática do Parlamento.

Afirma André Tavares ${ }^{9}$ que “a doutrina da separação dos poderes serve atualmente como um técnica de arranjo da estrutura política do Estado, implicando a distribuição por diversos órgãos de forma não exclusiva, permitindo o controle recíproco, tendo em vista a manutenção das garantias individuais consagradas no decorrer do desenvolvimento humano"10.

O que se costuma chamar de separação de poderes, na verdade nada mais é do que distribuição de determinadas funções a diferentes órgãos do Estado. A utilização do termo "poderes", embora enraizada, deve ser entendida de maneira figurativa ${ }^{11}$.

A distinção entre as funções legislativa, executiva e judiciária aparece com um claro intuito prescritivo e garantístico, qual seja, a separação orgânico-pessoal de referidas funções, imposta em nome da liberdade e da segurança individuais.

Foi, no entanto, o dogma da redução do Estado ao Direito que passou a identificar a teoria da separação dos poderes com a teoria da diferenciação dogmática das funções do Estado, de acordo com critérios jurídicos. Ou seja, o sentido político da doutrina da separação dos poderes ficou postergado, restando a idéia de que a cada poder corresponderia exclusivamente uma função materialmente definida (a isto se reduzia o princípio da separação dos poderes).

À função legislativa cabia a edição de normas gerais, abstratas e inovadoras do ordenamento, à função jurisdicional competia a conservação e a tutela do ordenamento jurídico mediante o proferimento de decisões aos casos concretos, e à

\footnotetext{
${ }^{9}$ TAVARES, André Ramos. Curso de Direito Constitucional. São Paulo: Saraiva, 2003, p. 864.

10 “A acumulação de todos os poderes, legislativos, executivos e judiciais, nas mesmas mãos,sejam estas de um, de poucos ou de muitos, hereditárias, auto-nomeadas ou eletivas, pode se dizer com exatidão que constitui a própria definição de tirania”. MADISON, James; HAMILTON, Alexander; JAY, John. O Federalista - Um comentário à Constituição Americana. Trad. Reggy Zacconi de Moraes. Rio de Janeiro: Editora Nacional de Direito, 1959, p. 196.

${ }^{11}$ LOEWENSTEIN, Karl. Teoria de la Constitución. Trad. Alfredo Gallego Anabitarte. Barcelona: Ed. Ariel, 1970, p. 55.
} 
função executiva ou administrativa restava realizar os objetivos do Estado, atuando concretamente dentro dos limites traçados pela lei. Percebeu-se, no entanto, que havia atos de igual natureza provenientes de mais de um dos órgãos, com o que se estabeleceu que desimportava que tipo de ato tinha sido praticado pelo legislativo, pois ele seria sempre considerado um ato legislativo; da mesma forma desimportava o tipo de ato praticado pelo judiciário, seria sempre um ato jurisdicional; assim como desimportava que ato o executivo tinha praticado, pois seria sempre considerado um ato executivo ou administrativo. À luz dessa classificação, o princípio da separação dos poderes transformou-se numa categoria com valor apriorístico, sendo que não era isso que realmente se buscava.

Esta classificação das funções estatais, consubstanciada no entendimento de que o Estado e o Direito se identificam foi rechaçada por Hans Kelsen ${ }^{12}$, na sua Teoria Pura do Direito. Kelsen procurou demonstrar que as funções estatais se reduzem necessariamente a duas: a legislativa (criação do Direito) e a executiva (aplicação do Direito), excluindo a autonomia de uma função administrativa identificada pelo objetivo que o Estado persegue. Para Kelsen, a estrutura da ordem jurídica é escalonada, e cada ato jurídico-estadual é, ao mesmo tempo, expressão das duas funções do Estado: é ato legislativo (criação do Direito em relação ao ato imediatamente inferior na escala de que é parâmetro de validade), e é também ato executivo (execução do Direito em relação ao ato imediatamente superior e válido na medida em que se conformar com o que este estabelece); assim, só nos extremos opostos da escala é que se poderia falar em ato de pura criação jurídica ou ato de pura execução ${ }^{13}$.

Desta forma, ao afirmar que o contraste entre as funções do Estado era apenas relativo, Kelsen retirou da teoria da separação dos poderes a sua sustentabilidade enquanto teoria da diferenciação material das funções jurídicas.

A função política ${ }^{14}$, por sua vez, não estava inserida dentro de nenhuma das funções do Estado (legislativa, administrativa e judiciária) e acabou por ser considerada uma função juridicamente livre, fora da teoria jurídica do Estado, sendo vista como de competência exclusiva do monarca (titular do governo), embora pudesse ser atribuída ao órgão legislativo nos regimes parlamentares (Jellinek). No Estado pós-dualista referida função foi atribuída a um processo cooperativo entre parlamento e governo. Essa idéia existiu até pouco tempo.

$12 \mathrm{O}$ texto fundamental de Hans Kelsen sobre a teoria da separação dos poderes, enquanto teoria das funções jurídicas do Estado, é Die Lehre von den drei Gewalten oder Funktionen des Staates, in: Archiv für Rechts und Wirtschaftsphilosophie, Viena, 1928.

${ }^{13}$ PIÇARRA, Nuno. A Separação dos Poderes como Doutrina e Princípio Constitucional. Um contributo para o estudo das suas origens e evolução. Coimbra: Coimbra Editora Limitada, 1989, p. 249.

${ }^{14}$ Faz parte da função política a orientação e a direção da sociedade política em geral, a determinação do interesse público, a interpretação dos fins do Estado, a fixação de suas tarefas e a escolha dos meios materiais, técnicos e organizatórios adequados para realizar, além da manutenção e o desenvolvimento da ordem jurídica estadual. Mais recentemente a função política tende a definir-se como uma conexão de funções legislativas, regulamentares, planificadoras, administrativas e militares, de natureza econômica, social, financeira e cultural, dirigida à individualização e graduação de fins constitucionalmente estabelecidos, uma vez que o Estado é um executor da constituição. PIÇARRA, Nuno. A Separação dos Poderes como Doutrina e Princípio Constitucional. Um contributo para o estudo das suas origens e evolução. Coimbra: Coimbra Editora Limitada, 1989, p. 253. 
Como a constituição do Estado de Direito contemporâneo, no entanto, vincula juridicamente todo o poder que ela própria faz nascer, resta impossível aceitarmos a função política como juridicamente livre e constitucionalmente desvinculada.

Temos que lembrar, que não é de todo equivocado pensar que dentro da função política pode estar a função de fazer a lei, o que poderia nos levar a pensar que desnecessária seria a função legislativa, considerada durante muito tempo como função central.

No Estado de Direito contemporâneo, a lei deixa de ser um conceito essencialmente jurídico $^{15}$ (idéia de justa conduta ou proibição de conduta injusta), para ser, também, um conceito político que traduz as relações entre o jurídico e o político num determinado Estado (idéia de conveniência e oportunidade). A lei visa, então, ser também um ato típico da função política (decisões políticas - uma espécie de função administrativa do poder legislativo) sem a isso ficar reduzida, para que o legislador não se limite à edição de normas gerais e abstratas, tomando ele (legislador) medidas de alcance sócio-político.

Foi, portanto, em nome do bem comum, que no Estado democrático-social a lei deixou de ser considerada mera regra de conduta, geral e abstrata, aplicada aos casos concretos por tribunais independentes, passando a ser, também, ordens à administração e que por esta devem ser executadas ${ }^{16}$.

No Estado de Direito contemporâneo a fiscalização, o controle, virou o ponto nodal do princípio da separação dos poderes, e dentre os vários tipos de controle ressalta-se o controle jurisdicional ${ }^{17} 18$ tanto do poder legislativo, como do poder executivo.

Lembra Madison $^{19}$ que não há dúvidas de que os poderes não devem ser administrados completa nem diretamente por qualquer dos outros, e que nenhum deles deve ter, direta ou indiretamente, uma influência preponderante sobre os outros no tocante às suas administrações. Segundo o autor: "não se pode negar que o poder tende a estender-se e que se lhe deve refreiar eficazmente para que não passe dos limites que se lhe fixem”. Mas a pergunta que Madison faz é: quais as medidas práticas que podem ser tomadas para que cada poder possa se defender das invasões dos outros? E ele próprio conclui dizendo: “a só determinação em um pergaminho dos limites constitucionais dos vários departamentos não é suficiente salvaguarda

\footnotetext{
${ }^{15}$ Conceito jurídico de lei: norma jurídica, geral e abstrata, destinada a fixar duradouramente os direitos e deveres individuais, ou seja, seu objetivo principal era fixar estatutos, sem nenhuma função reformadora (que foi alcançada pela função política da lei no Estado de Direito contemporâneo).

${ }^{16}$ Inicialmente a lei tinha um caráter geral e abstrato, atualmente a lei busca um conteúdo adequado e não, necessariamente, geral e abstrato.

${ }^{17}$ A respeito da possibilidade de um controle externo do Judiciário sugere-se LIMA, Fernando Machado da Silva. Jurisdição Constitucional e Controle do Poder. Porto Alegre: Sérgio Antônio Fabris Ed., 2005, p. 244-248.

${ }^{18}$ Como já referido às páginas 39 e seguintes.

${ }^{19}$ MADISON, James; HAMILTON, Alexander; JAY, John. O Federalista - Um comentário à Constituição Americana. Trad. Reggy Zacconi de Moraes. Rio de Janeiro: Editora Nacional de Direito, 1959, p. 200, 201 e 204.
} 
contra usurpações que conduzem á concentração tirânica de todos os poderes governamentais nas mesmas mãos”.

Pergunta Madison ${ }^{20}$ a que expediente teremos que recorrer para mantermos na prática a divisão necessária do poder entre os diferentes departamentos, tal como estatui a Constituição? Ele responde afirmando que como todas as precauções de caráter externo tornaram-se inadequadas, o defeito deverá ser suprido idealizando a estrutura interior do governo de tal modo que sejam distintas as partes constituintes, e que suas relações mútuas sejam os meios de se conservarem uma às outras em seu sítio. Aduz, outrossim, que “a maior segurança contra a concentração gradual dos diversos poderes em um só departamento reside em dotar os que administram cada departamento dos meios constitucionais e dos motivos pessoais necessários para resistir às invasões dos demais”. Madison diz: “que é o governo senão a maior das censuras à natureza humana? (...) Ao organizar um governo (...) primeiramente há que capacitar o governo para mandar sobre os governados; e logo obrigá-lo a que se regule a si próprio. O fato de depender do povo é (...) o freio primordial indispensável sobre o governo; contudo (...) são necessárias precauções auxiliares”.

Para entrarmos na teoria da democracia também como oposição ao Estado absoluto nos valemos das palavras de Norberto Bobbio ${ }^{21}$ :

O Estado moderno, liberal e democrático, surgiu da reação contra o Estado absoluto. Este nascimento, que tem como fases culminantes as duas revoluções inglesas dos século XVII e a Revolução Francesa, foi acompanhado por teorias políticas cujo propósito fundamental é o de encontrar um remédio contra o absolutismo do poder do príncipe. Na tradição do pensamento político inglês, que ofereceu a maior contribuição para a solução deste problema, dá-se o nome específico de 'constitucionalismo' ao conjunto de movimentos que lutam contra o abuso do poder estatal.

O problema fundamental que preocupa os ‘constitucionalistas' é o seguinte: se o príncipe tem um poder absoluto, pode abusar dele. Como se pode impedir o abuso do poder? Não se pode impedir, senão de um modo: limitando-o. Trata-se então de descobrir as várias formas para impedir o abuso do poder: as teorias políticas modernas estão todas voltadas para a busca da solução com relação a este problema. Consideramos que se podem classificar três grandes grupos, em busca do remédio a ser preferencialmente proposto contra o abuso do poder;

1) Teoria dos direitos naturais, ou jusnaturalismo: Segundo esta teoria, o poder do Estado tem um limite externo: que decorre do fato de que, além do direito proposto pela vontade do príncipe (direito positivo ${ }^{22}$ ), existe um direito que não é proposto por vontade alguma, mas pertence ao indivíduo, a todos os indivíduos,

${ }^{20}$ MADISON, James; HAMILTON, Alexander; JAY, John. O Federalista - Um comentário à Constituição Americana. Trad. Reggy Zacconi de Moraes. Rio de Janeiro: Editora Nacional de Direito, 1959, p. 211.

${ }^{21}$ BOBBIO, Norberto. Direito e Estado no Pensamento de Emanuel Kant. Trad. Alfredo Fait. Brasília: Editora Universidade de Brasília, 1997, p. 15-17.

22 "O Direito natural, ao contrário do Direito Positivo, seria comum a todos e, ligado à própria origem da humanidade, representaria um padrão geral, a servir como ponto de Arquimedes na avaliação de qualquer ordem jurídica positiva”. LAFER, Celso. A reconstrução dos Direitos Humanos. São Paulo: Companhia das Letras, 1988, p. 37. 
pela sua própria natureza de homens, independentemente da participação desta ou daquela comunidade política. Estes direitos são os direitos naturais que, preexistindo ao Estado, dele não dependem, e, não dependendo do Estado, o Estado tem o dever de reconhecê-los e garanti-los integralmente. Os direitos naturais constituem assim um limite ao poder do Estado, pelo fato de que o Estado deve reconhecê-los, não podendo violá-los, pelo contrário, deve assegurar aos cidadãos o seu livre exercício. O Estado que se modela segundo o reconhecimento dos direitos naturais individuais é o Estado liberal, no sentido originário da palavra.

2) Teorias da separação dos poderes: Existem outras teorias que impõem ao Estado limites internos: independentemente do fato que o poder estatal tenha que deter-se frente a direitos preexistentes ao Estado, as mesmas sustentam que a melhor maneira de limitar-se este poder é quebrá-lo. Trata-se de conseguir que: a) a massa do poder estatal não seja concentrada numa só pessoa, mas distribuída entre diversas pessoas; b) que as diferentes funções estatais não sejam confundidas num só poder, mas sejam atribuídas a órgãos distintos. Segundo esta teoria, o limite do poder nasce da sua própria distribuição por duas razões: 1) não existirá mais uma só pessoa que tenha todo o poder, mas cada uma terá somente uma porção do mesmo; 2) os órgãos distintos aos quais serão atribuídos funções distintas se controlarão reciprocamente (balança ou equilíbrio de poderes) de maneira que ninguém poderá abusar do poder que lhe foi confiado. Se se consideram como funções fundamentais do Estado a função legislativa, a executiva e a judiciária, a teoria da separação dos poderes exige que existam tantos poderes quantas são as funções e que cada um dos poderes exerça uma só função, assim que possa surgir o Estado desejado por esta teoria, Estado que foi também chamado de Estado Constitucional, quer dizer aquele Estado no qual os poderes legislativo, executivo e judiciário são independentes um do outro e em posição tal que podem controlar-se reciprocamente.

3) Teorias da soberania popular ${ }^{23}$ ou democracia. Existe uma terceira maneira de opor-se ao Estado absoluto do príncipe, proposta pelas teorias democráticas. Segundo estas teorias, não se trata de conter o poder limitando o mesmo por meio de direitos naturais ou por meio da distribuição para órgãos diferentes, mas de alcançar a participação de todos os cidadãos. Trata-se de uma verdadeira quebra do poder estatal, o qual, pertencendo a todos, disse Rousseau, é como se não pertencesse totalmente a ninguém. Veja-se que, nesta teoria, o remédio contra o abuso do poder não é tanto a limitação do poder, mas a mudança incondicional do seu titular. O ponto de partida desta teoria é a hipótese de que o poder fundamentado no consenso popular não possa cometer abusos, ou seja, que o povo não possa exercer o poder que lhe pertence contra si mesmo. Então, a diferença entre a teoria democrática e as outras duas consiste nisso: frente ao abuso do poder, as duas primeiras buscam motivos para limitar o poder absoluto; a terceira considera que o único remédio seja o fato de atribuir o poder a quem por sua própria natureza não pode abusar dele, ou seja, à vontade geral.

\footnotetext{
23 "As decisões judiciais fazem parte do exercício da soberania do Estado, que, embora disciplinada pelo direito, é expressão do poder político”. DALLARI, Dalmo de Abreu. O Poder dos Juízes. São Paulo: Saraiva, 2002, p. 90.
} 
A grande maioria das Constituições ${ }^{24}$ repete o enunciado: “Todo poder emana do povo e em seu nome será exercido”, mas como é possível, então, que tenhamos chegado à situação atual ${ }^{25}$

Democracia significa, literalmente, o poder, Kratos, do povo, demos. A Revolução Francesa foi feita em nome desse ideal e sob o lema liberdade, igualdade e fraternidade.

$\mathrm{Na}$ verdade, salienta Fernando Lima, ${ }^{26}$ "não se trata de governo do povo, porque o povo não é capaz de reconhecer os seus reais interesses, porém de governo sobre o povo, apesar do povo, e no 'interesse' do povo”, para o autor essa tem sido a dissimulação de outras verdadeiras intenções e que vem justificando tiranias. Diz ele:

A luta pelo poder não está sendo vencida pelo povo. Ao contrário, devido às condições atuais, em que a detenção do poder, do capital e da tecnologia possibilita os meios indispensáveis para a própria ampliação desse mesmo poder, o que se observa é que os países pobres, ou periféricos, do assim denominado Terceiro Mundo, têm cada vez menor esperança de romper as cadeias do subdesenvolvimento. E o pior é que, quando são levados a certas aventuras desenvolvimentistas, financiadas por interesses estrangeiros, também prejudicam cada vez mais o seu povo e criam problemas de difícil solução.

O grande inimigo da Democracia, tanto no plano interno quanto no das relações internacionais, é o Lucro, desde que associado à injustiça e á desmedida ganância, posto que a ausência de limitação legal permite que sejam postergadas, em nome da liberdade contratual e dos princípios da livre empresa, todas as garantias que deveriam ser dadas ao povo, sempre o grande prejudicado pela ausência da norma jurídica eficaz.

Para Fernando Lima ${ }^{27}$ não temos como pedir ao povo que controle o poder pois "sem um controle efetivo do poder, em todas as suas manifestações, é apenas hipocrisia dizer que temos uma democracia, que o poder pertence ao povo, ou que o povo é titular do Poder Constituinte ${ }^{28,}$.

${ }^{24}$ Sobre a Constituição de Novo Hampshire, de Massachusetts, de Rhode Island e Connecticut, de Nova York, de Nova Jersey, da Pensilvânia, Carolina do Norte, Carolina do Sul e da Geórgia ler MADISON, James; HAMILTON, Alexander; JAY, John. O Federalista - Um comentário à Constituição Americana. Trad. Reggy Zacconi de Moraes. Rio de Janeiro: Editora Nacional de Direito, 1959, p. 197-200.

${ }^{25}$ Madison também entende que dar o poder ao povo não é adequado, senão vejamos: "Averiguamos no último artigo que as simples declarações escritas na Constituição não bastam para manter os diversos departamentos no círculo de seus direitos legais. Neste, demonstramos, que apelar ao povo, em ocasiões, não seria uma providência adequada nem efetiva para o referido objetivo”. MADISON, James; HAMILTON, Alexander; JAY, John. O Federalista - Um comentário à Constituição Americana. Trad. Reggy Zacconi de Moraes. Rio de Janeiro: Editora Nacional de Direito, 1959, p. 207.

${ }^{26}$ LIMA, Fernando Machado da Silva. Jurisdição Constitucional e Controle do Poder. Porto Alegre: Sérgio Antônio Fabris Ed., 2005, p. 59-60.

${ }^{27}$ LIMA, Fernando Machado da Silva. Jurisdição Constitucional e Controle do Poder. Porto Alegre: Sérgio Antônio Fabris Ed., 2005, p. 64.

28 "Nem sequer por unanimidade pode um povo decidir (ou consentir que se decida) que um homem morra ou seja privado sem culpa de sua liberdade, que pense ou escreva ou não pense ou não escreva de um dado modo, que não se reúna ou não se associe a outros, que se case ou não se case com certa pessoa ou fique com ela indissoluvelmente ligado, que tenha ou não tenha filhos, que faça ou não faça tal trabalho, ou 
Para a Profa. Carmem Rocha ${ }^{29}$ : “o Poder não pode 'parar’ o Poder, como dizia Montesquieu. Somente a cidadania ativa pode 'parar' o Poder e tornar efetivos os direitos consagrados na Constituição.

E, como ainda salienta Fábio Comparato ${ }^{30}$ : "no regime democrático, o atributo maior da soberania popular consiste em constitucionalizar a nação", e para que isso ocorra mister que os cidadãos sejam responsáveis e verdadeiramente se importem com os problemas políticos.

Gustav Radbruch ${ }^{31}$, por seu turno, comenta que: “com Rousseau, a democracia rejeita a divisão de poderes, pois aspira precisamente ao absolutismo da maioria, combatido por aquela".

Explicando como se dá a transformação do Estado absoluto em Estado de Direito, ligando a democracia ao Estado de direito e falando quem pode, como se pode e o que se pode decidir Luigi Ferrajoli ${ }^{32}$ traz que:

É com a estipulação constitucional de tais deveres públicos que os direitos naturais se tornam direitos positivos invioláveis, e muda, por isso, a estrutura do Estado, não mais absoluto mas limitado e condicionado. 'A declaração de direitos' diz o art. 1 da segunda parte da Constituição francesa de 1795, 'contém as obrigações dos legisladores'. Estas obrigações, tanto quanto lhe é efetivamente exigível a satisfação, formam as garantias dos cidadãos: que são contra a maioria, sendo postas contra qualquer poder para tutela sobretudo dos indivíduos e das minorias que não têm poder; e são contra a utilidade geral, tendo como escopo exclusivo a tutela dos direitos individuais. Graças a elas o legislador, mesmo se é ou representa a maioria do povo, não é nunca onipotente, dado que a violação delas confere vigor às normas não somente injustas mas também inválidas, e portanto censuráveis e sancionáveis não só politicamente mas também juridicamente.

outras coisas similares. A garantia desses direitos vitais é condição indispensável da convivência pacífica. Por isso a sua lesão por parte do Estado justifica não simplesmente a crítica ou dissenso, como por questões não vitais sobre as quais vale a regra da maioria, mas a resistência à opressão, até a guerra civil. 'Sobre questões de existência' foi dito ‘não se deixa à minoria’”. FERRAJOLI, Luigi. Direito e Razão. Teoria do Garantismo Penal. São Paulo: Editora Revista dos Tribunais, 2002, p. 690.

${ }^{29}$ ROCHA, Carmem Lúcia Antunes. Democracia, Constituição e Administração Pública, in Boletim de Direito Administrativo, $n^{\circ}$ 9, 1999, p. 731.

${ }^{30}$ COMPARATO, Fábio Konder. Réquiem para uma Constituição. In: O Desmonte da Nação. Petrópolis: Vozes, 1999, p. 16.

${ }^{31}$ RUDBRUCH, Gustav. Filosofia do Direito. São Paulo: Martins Fontes, 2004, p. 98. Nas palavras do autor, na mesma página 98: "Na concepção democrática, ao contrário, o indivíduo coloca a sua liberdade pré-estatal inteiramente à disposição da vontade do Estado, da vontade da maioria, reservando-se como compensação a possibilidade de participar na formação dessa vontade majoritária. Dessa diversidade das suas concepções fundamentais resultam para o liberalismo e a democracia princípios bem distintos de organização política, a já conhecida oposição entre Montesquieu e Rousseau: o liberalismo declara-se favorável à teoria de divisão dos poderes de Montesquieu, cujo sentido é aproveitar a rivalidade entre ambos os pretendentes ao absolutismo - o monarca e a maioria - a favor dos incólumes direitos de liberdade do indivíduo".

${ }^{32}$ FERRAJOLI, Luigi. Direito e Razão. Teoria do Garantismo Penal. São Paulo: Editora Revista dos Tribunais, 2002, p. 690. 
É assim que a transformação do Estado absoluto em Estado de direito ocorre simultaneamente à transformação do súdito em cidadão, isto é, em um sujeito titular de direitos não mais exclusivamente 'naturais' mas 'constitucionais' em relação ao Estado, que se torna, por sua vez, vinculado em relação àquele. $\mathrm{O}$ denominado contrato social, uma vez traduzido em pacto constitucional, não é mais uma hipótese filosófico-política, mas um conjunto de normas positivas que obrigam entre si o Estado e o cidadão, tornando-os dois sujeitos de soberania reciprocamente limitada.

Acerca do direito de veto e do princípio democrático Nuno Piçarra ${ }^{33}$ afirma um entendimento que se traz na íntegra:

A este entendimento do princípio da separação dos poderes de que o direito de veto do executivo é corolário e em que o poder se pode opor ao poder, com prejuízo da regra da maioria ${ }^{34}$, foi contraposto, em nome do princípio democrático, um sistema de separação estrita de poderes, em que os eventuais abusos cometidos pelos vários órgãos constitucionais eleitos não seriam prevenidos ou corrigidos reciprocamente, através dos mecanismos de que cada um para o efeito dispusesse, mas sim pela intervenção do povo eleitor. Era o ressurgir da velha idéia de separação dos poderes dos republicanos ingleses, em que não havia lugar a freios e contrapesos e, sobretudo, em nome do princípio democrático, não havia lugar a qualquer direito de veto sobre as decisões majoritárias do órgão representativo eleito, ainda que (como seria o caso) o próprio titular do direito de veto fosse também democraticamente eleito.

Mais uma vez, a relação poder-contrapoder se não constituiria entre órgãos constitucionais comungando do mesmo princípio de legitimidade, mas entre cada um desses órgãos e o povo eleitor. Entre os vários órgãos constitucionais eleitos não haveria lugar a recíprocas interferências por cada um deles ser mero delegado do povo soberano, apenas ele ficando em relação direta.

Os checks and balances eram, assim, rejeitados em nome da democracia, pois punham em causa, na prática, o princípio de que apenas o delegante, ou seja o povo, pode controlar o exercício do poder por parte do órgão delegado e não qualquer outro órgão delegado. Um órgão estadual com poderes de controle sobre o órgão, por excelência, representativo, ou seja, o legislativo exerceria um poder superior ao do povo soberano. Deste ponto de vista, os freios e contrapesos, longe de se mostrarem o complemento natural de uma separação orgânica-funcional, eram incompatíveis com ela e eram, sobretudo, incompatíveis com uma concepção de democracia que não admite limites ao

${ }^{33}$ PIÇARRA, Nuno. A Separação dos Poderes como Doutrina e Princípio Constitucional. Um contributo para o estudo das suas origens e evolução. Coimbra: Coimbra Editora Limitada, 1989, p. 182.

34 "A regra da maioria adotada pelas democracias contemporâneas - sempre combinada ao crescente processo de alargamento da cidadania política ao longo dos últimos duzentos anos - fez da participação política de massas um fenômeno inédito na história da civilização. A tensão entre racionalidade formal e racionalidade material está sempre por trás do ideal de que a produção democrática do direito só se legitima com o beneplácito da maioria. Daí a inquietação, por exemplo, de Ripert: 'ao chegar ao poder a democracia quer um direito novo' ... 'o sufrágio universal deu o poder ao maior número' ... 'hoje é o número que faz a lei'. Com isso, muda-se a racionalidade jurídica, a técnica de sua produção e o ritmo de suas transformações”. CAMPILONGO, Celso Fernandes. Direito e Democracia. São Paulo: Max Limonad, s.d, p. 56. 
poder das assembléias legislativas que não sejam a eleição mais ou menos freqüente dos seus titulares, ou seja, que não decorram apenas do exercício do poder eleitoral.

Impregnada pelo ideário liberal, a separação dos poderes identifica-se com a balança dos poderes: é, no essencial, colocada ao serviço da limitação interna do poder do Estado mediante a sua estruturação plural e as recíprocas oposições que aí radicarão.

Impregnada pelo ideário democrático, a separação dos poderes é colocada ao serviço da supremacia do parlamento-legislador, mediante a exclusão de qualquer controle intra-estadual sobre as suas decisões majoritárias, que apenas o eleitorado sancionará.

As duas posições defrontaram-se quando do debate que precedeu a aprovação da Constituição de 1787. A que triunfou - um sistema de freios e contrapesos entre órgãos constitucionais democraticamente eleitos, direta ou indiretamente, pelo mesmo povo soberano - foi a genuína contribuição norteamericana para a moderna teoria constitucional.

Sendo certo que se pode ler ou projetar no poder de veto atribuído ao Presidente o desejo de precaução contra uma eventual maioria tirânica de não proprietários, a verdade é que ele veio a constituir mais tarde 'a prerrogativa tribunícia do povo’ contra uma maioria oligárquica no Congresso.

A prática constitucional veio, por último, revelar que o sistema de freios e contrapesos determinou, afinal, não um equilíbrio permanente entre os 'poderes separados’, mas sim a predominância cíclica de cada um deles. (grifo nosso)

Segundo Hans Kelsen ${ }^{35}$, à questão de saber se a separação dos poderes é ou não um princípio democrático não cabe uma resposta única. Do ponto de vista da ideologia, uma separação dos poderes, atribuição da legislação e da execução à órgãos diferentes, não corresponde à idéia de que o povo só deva ser governado por si mesmo. Deste pensamento resulta a idéia de que todos os poderes e, consequentemente, todas as funções do Estado deveriam ser reunidas nas mãos do povo ou, pelo menos, do parlamento que o representa.

Lembra kelsen, que a separação dos poderes não visa abrir a via democrática, mas, ao contrário, conservar a possibilidade de o monarca ainda exercer um poder próprio no campo da execução. De qualquer modo que se organize o jogo das forças no Estado, a separação dos poderes traz que o legislativo policefálico - no qual só o povo está representado - não pode impor a própria supremacia; portanto, é quase uma ironia da história que uma república como os Estados Unidos aceite a separação dos poderes e que a leve a extremos exatamente em nome da democracia. Para o autor, quando o executivo é confiado a um presidente - eleito diretamente pelo povo - isso resulta mais em um enfraquecimento do princípio da soberania popular, do que em um fortalecimento da mesma, pois quando à frente da população está um único indivíduo eleito, a idéia de representação do povo perde o fundamento ${ }^{36}$.

${ }^{35}$ KELSEN, Hans. A Democracia. Trad. Ivone Benedetti. São Paulo: Martins Fontes, 1993, p. 89 e seguintes.

36 "Aquilo que num parlamento em que estejam compreendidos todos os partidos talvez seja possível, isto é, que da cooperação de todas essas forças resulte algo que possa ser considerado vontade nacional, é, ao 
Na mesma linha de raciocínio Kelsen ${ }^{37}$ ainda afirma:

Todavia, a separação dos poderes talvez aja também em sentido democrático: em primeiro lugar, na medida em que significa uma divisão do poder, cuja concentração, favorável à expansão e ao exercício arbitrário, ela impede; em segundo lugar, na medida em que tende a subtrair o importante estágio da formação da vontade geral do Estado à influência direta do governo, permitindo que os súditos a influenciem diretamente e reduzindo a função do governo à ratificação legislativa das leis.

\subsection{A Separação dos Poderes por Montesquieu e a Doutrina dos Checks} and Balances

A contribuição do Senhor de La Brède foi crucial para o reconhecimento da existência dos três poderes, uma vez que foi quem elevou à teoria a separação dos poderes, buscando os elementos formais para tanto na experiência inglesa, uma vez que ele conhecia a política inglesa muito pelo fato de ter morado por dois anos na Inglaterra.

No livro XI, do Espírito das Leis, Montesquieu deixa claro que está buscando desenhar os traços fundamentais da organização política a fim de alcançar e garantir a liberdade política. Ressalta-se, todavia, que liberdade para ele é "fazer tudo aquilo que as leis facultam”38, e essa liberdade é a típica dos governos moderados quando não há o abuso do poder, referindo ele que a democracia e a aristocracia não são, por sua natureza, Estados livres.

Enfatiza Montesquieu que para que não exista o abuso do poder mister que “o poder contenha o poder”, e que "uma constituição pode ser feita de tal forma, que ninguém será constrangido a praticar coisas que a lei não obriga, e a não fazer aquelas que a lei permite"39.

Resumido por Cezar Saldanha ${ }^{40}$, o modelo proposto por Montesquieu, receita de justaposição, tem o intuito de encontrar a mesma liberdade da Inglaterra e está formulado da seguinte maneira:

a) Dividir o poder estatal entre os três órgãos existentes (Rei, Parlamento e Juízes), b) atribuindo-se a cada um deles uma das três funções em que se poderia

contrário, impossível no caso do presidente designado por eleição presidencial direta e que, por isso mesmo, independe totalmente do parlamento e, por outro lado, não é controlável por todo o corpo popular, imenso e incapaz de agir, tanto quanto na monarquia hereditária; aliás, as perspectivas de autocracia embora limitadas no tempo - podem, em certos casos, ser maiores no regime presidencial do que na monarquia hereditária. Nesse caso o tipo de investidura não desempenha papel decisivo. A escassa afinidade existente entre a idéia de representação e o princípio democrático logo é reconhecida pelo fato de a autocracia servir-se da mesma ficção”. KELSEN, Hans. A Democracia. Trad. Ivone Benedetti. São Paulo: Martins Fontes, 1993, p. 90.

${ }^{37}$ KELSEN, Hans. A Democracia. Trad. Ivone Benedetti. São Paulo: Martins Fontes, 1993, p. 91.

${ }^{38}$ MONTESQUIEU, Charles Louis de Sécondat, baron de la Brède et de. Do Espírito das Leis. Trad. Jean Melville. São Paulo: Editora Martin Claret, 2004, p. 164.

${ }^{39}$ MONTESQUIEU, Charles Louis de Sécondat, baron de la Brède et de. Do Espírito das Leis. Trad. Jean Melville. São Paulo: Editora Martin Claret, 2004, p. 165.

${ }^{40}$ SOUZA JÚNIOR, Cezar Saldanha. O Tribunal Constitucional como Poder. Uma nova teoria da divisão dos poderes. São Paulo: Memória Jurídica, 2002, p. 56-57. 
classificar a política (função executiva, função legislativa e função judicial) e de uma forma a mais separada ou pura possível, c) posicionados os três órgãos (com o exercício especializado das respectivas funções) em um mesmo plano de igualdade e de hierarquia, reforçado com mecanismos adicionais de travamento - a independência e harmonia de que falam as constituições.

Esta fórmula, simples de aparência, articula sagaz e prudentemente:

$1^{\circ}$. uma classificação ternária de órgãos sociais que vinham evolvendo do Medievo: o Rei (a Coroa), o Parlamento, reunindo a nobreza de espada (na Câmara Alta) e os Comuns ou Terceiro Estado (na Câmara Baixa), bem como o corpo de magistrados (a burocracia togada); nesses três órgãos todas as forças válidas da época estavam representadas, cada qual cumprindo um determinado papel social; o objetivo de Montesquieu é o de instituir um 'governo moderado', ou seja, o 'regime misto' recomendado por Políbio, Cícero e S. Tomás, capaz de combinar, num mesmo conjunto de arranjos, o governo de um (monarquia), o governo de alguns (aristocracia) e o governo de muitos (democracia), maximizando as virtudes e minimizando os defeitos de cada um dessas formas quando consideradas isoladamente;

$2^{\circ}$. uma classificação, também ternária, das funções políticas que, desde Aristóteles, ganhava corpo (e um crescente viés jurídico), a saber, a função executiva, a função legislativa e a função judicial; Montesquieu eleva essa classificação a cânone fundamental da nova ordem liberal, mesmo não tendo sido por ele apresentada com pretensões de cientificidade;

$3^{\circ}$. uma alocação, a mais exclusiva e separada possível, para cada órgão social, de uma das funções políticas (puissances), transformando-os em poderes políticos (pouvoirs); assim, o Rei, com a função executiva, é o Poder Executivo; o Parlamento, com a função legislativa, o Poder Legislativo; os juízes, com a função judiciária, o Poder Judiciário; aí está, stricto sensu, o princípio da separação das funções políticas, garantia da pureza funcional de cada uma delas e instrumento poderoso no travamento recíproco dos poderes;

$4^{\circ}$. um mesmo plano horizontal e mecânico, no qual todos os poderes estariam em pé de igualdade em tudo (hierarquia, independência e potência jurídica), criando-se ipso facto um ambiente de paralisia (Montesquieu usa os termos ‘repouso’ e ‘inação’), de modo que seriam, pelo ‘movimento necessário das coisas, forçadas a andar em harmonia'.

$5^{\circ}$. um espaço para o estabelecimento adicional de freios e contrapesos recíprocos, de modo que 'o poder possa deter o poder' (por exemplo, o poder de veto ${ }^{41}$, o poder de convocar o Parlamento, o poder de impedir ministros e juízes, etc...).

De acordo com Rodrigo Valin de Oliveira ${ }^{42}$, cuja tese de doutorado foi intitulada O Poder Moderador, é necessário apontar, num determinado governo, quais são os

\footnotetext{
41 “O poder executivo deve tomar parte na legislação por meio do seu direito de veto, sem o que logo ficaria despojado de suas prerrogativas”. MONTESQUIEU, Charles Louis de Sécondat, baron de la Brède et de. Do Espírito das Leis. Trad. Jean Melville.São Paulo: Editora Martin Claret, 2004, p. 173.

${ }^{42}$ OLIVEIRA, Rodrigo Valin de. O Poder Moderador. Tese apresentada ao Curso de Doutorado da Faculdade de Direito da Universidade de São Paulo. Orientador: Manoel Gonçalves Ferreira Filho. São Paulo: 2003, p. 35, 36, 37 e 44 .
} 
mecanismos jurídicos propícios à efetivação da liberdade, e a separação dos poderes é um deles. Afirma ele que o contexto histórico da produção da obra do Barão de La Brède revela a intenção de conciliar forças sociais através do equilíbrio entre os diversos atores sociais, pois a idéia de moderação engendra a idéia de separação de poderes. Segundo o autor, o constitucionalismo moderno descobriu em o Espírito das Leis, os meios necessários à formulação de uma técnica de controle do poder, com o claro objetivo de resguardar a liberdade. O enriquecimento do constitucionalismo, no entanto, contribuiu para o declínio do princípio da separação dos poderes, pois a Constituição passou a experimentar alterações estruturais, e Executivo e Judiciário passaram a ter um peso e proporções desconhecidos, diferentes do que traçara o Barão.

Na mesma tese Rodrigo Valin ${ }^{43}$ lembra que no capítulo VI, livro XI, da obra de Montesquieu, dedicado à Constituição inglesa, o Barão anunciou três espécies ${ }^{44}$ de poder: o Legislativo, o Executivo das coisas que dependem do direito das gentes e o Executivo das coisas que dependem do direito civil informando que:

O Poder Legislativo ${ }^{45}$ define-se, de início, em razão de sua formação: fazer, corrigir ou ab-rogar as leis. Encarna, na concepção de Montesquieu, a vontade geral do Estado. Deve ser confiado a um corpo de nobres e a um corpo de representantes ${ }^{46}$ do povo. Não é recomendável, por conseguinte, que o povo exerça diretamente o Poder Legislativo: tal exercício seria impossível nos grandes estados e pouco útil nos pequenos. De fato, o povo revela-se incapaz de discutir os assuntos políticos. Resta-lhes, no máximo, a capacidade de

43 OLIVEIRA, Rodrigo Valin de. O Poder Moderador. Tese apresentada ao Curso de Doutorado da Faculdade de Direito da Universidade de São Paulo. Orientador: Manoel Gonçalves Ferreira Filho. São Paulo: 2003, p. 38-39.

44 "Montesquieu diz que eles são três e logo em seguida praticamente os reduz a dois, o legislativo e o executivo, mas pouco adiante desdobra este último em 'executivo das coisas que dependem do Direito Civil'. E este último atribuiu o poder de punir e julgar os conflitos entre particulares. E conclui: 'nós chamaremos a este último o poder de julgar’. (...) Montesquieu diz que não haverá liberdade se o poder de julgar não for separado do poder legislativo e do executivo, concluindo que se o juiz tivesse também um dos outros poderes ele ganharia a força de um opressor. Assim, ao mesmo tempo em que sustenta a necessidade de um corpo independente exercendo o poder de julgar, para que os outros poderes não sejam demasiados fortes, ele teme que o excesso de poder dos magistrados crie riscos para a liberdade. Por isso, considera necessária a magistratura separada dos demais poderes, mas insiste em que 'os juízes não devem ser mais do que a boca que pronuncia as palavras da lei, seres inanimados que não podem moderar nem a força nem o rigor da lei’”. DALLARI, Dalmo de Abreu. O Poder dos Juízes. São Paulo: Saraiva, 2002, p. 91.

${ }^{45}$ Na obra de Montesquieu a supremacia do Legislativo está implícita, pois referido poder constitui a vontade geral do Estado, ao passo que o Executivo se ocupa da execução dessa vontade geral, a preponderância do Legislativo, no entanto, não chega a implicar subordinação DALLARI, Dalmo de Abreu. O Poder dos Juízes. São Paulo: Saraiva, 2002, p. 90. Nuno Piçarra, no entanto, entende que o Legislativo e o Executivo "estão entre si numa relação de função exclusivamente soberana e criadora (a função legislativa) para função subordinada e estritamente aplicadora (função executiva)” PIÇARRA, Nuno. A Separação dos Poderes como Doutrina e Princípio Constitucional. Um contributo para o estudo das suas origens e evolução. Coimbra: Coimbra Editora Limitada, 1989, p. 95. Para o Barão, a lei corporifica a vontade humana, mas a idéia de que a vontade do legislador estivesse apta a declarar o Direito começa a ser posta em questão.

46 “A grande vantagem dos representantes é que estes são capazes de discutir as questões públicas. O povo não é, de modo algum, apto para isso, fato que constitui um dos grandes inconvenientes da democracia”. MONTESQUIEU, Charles Louis de Sécondat, baron de la Brède et de. Do Espírito das Leis. Trad. Jean Melville. São Paulo: Editora Martin Claret, 2004, p. 168. 
identificar os homens aptos para tal missão (os representantes). A noção de representação, considerada a mais apropriada por Montesquieu, afasta-se daquela que mais tarde seria conhecida como teoria do mandato imperativo. Os representantes recebem uma instrução geral da parte dos eleitores, jamais uma instrução singular e determinada sobre cada assunto. Livra-se a voz da nação, assim, dos riscos da vagarosidade do processo ou dos caprichos de um dado parlamentar. Montesquieu, conforme interpreta Goyard-Fabre, posiciona-se favoravelmente ao sufrágio universal. $\mathrm{O}$ corpo de representantes detém a faculdade de estatuir; o corpo de nobres, em vez de tal atribuição, possui a faculdade de impedir. Caso estivesse investido da faculdade de estatuir, o ramo hereditário do Poder Legislativo, ocupado em conservar suas prerrogativas, de algum modo odiosas, ameaçaria a liberdade do Estado, desconhecendo os interesses do povo. A estrutura bicameral do Poder Legislativo, institucionalizando a distinção entre faculdade de estatuir e faculdade de impedir, contribui, de forma decisiva, para a realização do equilíbrio político almejado por Montesquieu.

O Poder Executivo ${ }^{47}$ (Poder Executivo das coisas que dependem do direito das gentes) ajusta-se, perfeitamente, ao pensamento de cariz liberal. Sua função restringe-se a decretar a paz ou a guera, receber ou enviar embaixadas, estabelecer a segurança interna e prevenir as invasões. A natureza da função, submetida aos imperativos e às dificuldades, típicos das decisões imediatas e instantâneas, define o titular mais apropriado. O monarca, portanto, exerce a função referida. Cabe ao Poder Executivo, assinala-s, ainda, o direito de decidir a respeito da oportunidade da convocação do Poder Legislativo. Define, também, o rei a duração da sessão do Poder Legislativo. Montesquieu descobre inconvenientes graves tanto num longo período sem reunião do Poder Legislativo como num período interminável de reunião do mesmo. De um lado, sem a atividade do corpo legislativo por um período considerável, reinaria a anarquia (ausência de leis) ou ressurgiria o absolutismo, pois o Executivo tenderia a assumir as prerrogativas do Legislativo. De outro lado, uma assembléia de legisladores reunida indefinidamente geraria no governo o vezo de defender as próprias prerrogativas, em vez de cumprir sua missão.

O terceiro dos poderes descritos por Montesquieu, o Poder de Julgar (Poder Executivo das coisas que dependem do Direito Civil), cumpre duas funções principais: punir os crimes e resolver os conflitos entre os particulares. Conforme assinala Montesquieu: 'o Poder de Julgar não deve ser dado a um Senado permanente, mas exercido por um grupo de pessoas retiradas do corpo do povo em certas épocas do ano, da maneira prescrita pela lei, para formar um tribunal que dure tanto quanto a necessidade o exigir'. A provisoriedade marca, logo, a configuração do Poder de Julgar, cujos membros não se acham vinculados à determinada profissão ou a dado estamento. Num tal contexto, o temor da magistratura substitui o temor dos magistrados. A potência de julgar

\footnotetext{
47 "Se o poder executivo não tem o direito de controlar os empreendimentos do corpo legislativo, este tornar-se-á despótico, pois, como pode atribuir a si todo o poder que pode imaginar, destruirá todos os outros poderes. Mas não é preciso que o poder legislativo tenha reciprocamente a faculdade de refrear o poder executivo, porque, tendo a execução limites por sua natureza, seria inútil limitá-la, considerando-se, além disso, que o poder executivo é exercido sempre sobre coisas momentâneas (...). O poder legislativo (...) tem o direito e deve ter a faculdade de examinar de que modo as leis que ele promulgou foram executadas”. MONTESQUIEU, Charles Louis de Sécondat, baron de la Brède et de. Do Espírito das Leis. Trad. Jean Melville. São Paulo: Editora Martin Claret, 2004, p. 171.
} 
revela-se, de um modo ideal, indivisível e nula. O exercício da jurisdição, porém, para escapar aos perigos da arbitrariedade, deve conformar-se ao texto preciso da lei. Os juízes de Montesquieu, segundo a célebre expressão, nada mais são do que 'a boca que pronuncia as palavras da lei' ${ }^{48}$. Uma justiça de concepção personalista, sem maior apego às normas, provocaria o repúdio de Montesquieu. No entender de Goyard-Fabre, a idéia-força de Montesquieu reaparece neste ponto: a lei engendra e protege a liberdade $\mathrm{As}^{40}$.

O Barão propõe que o Judiciário seja exercido por "pessoas extraídas da classe popular" ${ }^{51}$," mas, ao mesmo tempo, sustenta que "é preciso que os nobres sejam citados a comparecer, não diante dos tribunais ordinários da nação, mas diante da parte do corpo legislativo composta de nobres"52, do que se depreende que em sua teoria existe uma função específica, neste caso a de julgar, bem como há a preocupação de que a magistratura não seja tão poderosa.

Já que o objetivo é, também, traçar a diferença entre a doutrina da separação dos poderes e do checks and balances, Nuno Piçarra ${ }^{53}$ sustentando que o checks and balances é uma das variantes da separação dos poderes aduz que:

Podem (os poderes), todavia, ganhar total autonomia numa constituição cujo substrato não seja uma sociedade estamental mas uma sociedade politicamente homogênea ou nivelada, que vise o mesmo objetivo: a limitação ou moderação do poder político, a partir da sua estruturação plural. Esta concepção essencialmente técnico-institucional da balança dos poderes serviu de ponto de partida à

\footnotetext{
48 “Se representassem uma opinião particular do juiz, viver-se-ia na sociedade sem saber precisamente quais os compromissos que nela são assumidos”. MONTESQUIEU, Charles Louis de Sécondat, baron de la Brède et de. Do Espírito das Leis. Trad. Jean Melville.São Paulo: Editora Martin Claret, 2004, p. 167.

${ }^{49}$ MONTESQUIEU, Charles Louis de Sécondat, baron de la Brède et de. Do Espírito das Leis. Trad. Jean Melville. São Paulo: Editora Martin Claret, 2004, p. 165.

50 "A versão de eficiência foi invocada por Montesquieu como fundamento para a necessidade de separação entre o poder executivo e poder judicial: um órgão pouco numeroso como o executivo não deve prosseguir uma função que exija a imparcialidade requerida pela função judicial, conseguida apenas na base de um órgão muito numeroso. A versão de eficiência serve, igualmente para fundamentar a necessidade de separação entre legislativo e executivo. A função legislativa, que se traduz basicamente em deliberações a partir de um debate contraditório, de natureza menos voluntarista do que cognoscitiva, será mais eficientemente prosseguida por um órgão colegial de tipo assembléia do que por um órgão singular. Em contrapartida, a função executiva, que exige quase sempre uma ação momentânea ou que se exerce sempre sobre coisas momentâneas, para ser eficazmente desempenhada deve caber a um órgão singular. Um órgão colegial numeroso não se mostra, por isso, estruturalmente adequado à prossecução da função executiva. A separação entre legislativo e executivo, como modo de possibilitar a responsabilização criminal dos titulares deste último perante aquele, está igualmente presente em Montesquieu, embora com a grande restrição que consiste em excluir dessa responsabilização perante o órgão legislativo o supremo titular d órgão executivo”. PIÇARRA, Nuno. A Separação dos Poderes como Doutrina e Princípio Constitucional. Um contributo para o estudo das suas origens e evolução. Coimbra: Coimbra Editora Limitada, 1989, p. 102-103.

${ }^{51}$ MONTESQUIEU, Charles Louis de Sécondat, baron de la Brède et de. Do Espírito das Leis. Trad. Jean Melville. São Paulo: Editora Martin Claret, 2004, p. 167.

${ }^{52}$ MONTESQUIEU, Charles Louis de Sécondat, baron de la Brède et de. Do Espírito das Leis. Trad. Jean Melville. São Paulo: Editora Martin Claret, 2004, p. 172.

${ }^{53}$ PIÇARRA, Nuno. A Separação dos Poderes como Doutrina e Princípio Constitucional. Um contributo para o estudo das suas origens e evolução. Coimbra: Coimbra Editora Limitada, 1989, p. 83.
} 
concepção dos constituintes norte-americanos, vindo a designar-se a partir de então por doutrina dos checks and balances ${ }^{54}$.

Sobre o mesmo tema Fernando Lima ${ }^{55}$ recorda que:

Nos Estados Unidos, a Constituição de 1787 adotou uma interpretação mais rígida da teoria da separação dos poderes, com a doutrina dos checks and balances, visando o controle recíproco dos poderes, sem, no entanto, a possibilidade da dissolução do Gabinete - nem existe essa idéia de um corpo homogêneo e solidário -, ou a possibilidade de dissolução antecipada do corpo legislativo antes do término dos mandatos, em decorrência das crises entre os poderes, conforme pode ocorrer no sistema parlamentarista. No presidencialismo, os ministros são nomeados e demitidos pelo Presidente e não dependem da confiança do corpo legislativo.

Nélson Saldanha ${ }^{56}$ ainda afirma: “a teoria (da separação dos poderes) deu formulação à experiência através da imagem conceitual dos checks and balances, cuja sutil e tácita fórmula foi tida durante os séculos XVIII e XIX como uma espécie de ‘segredo da Constituição britânica’”. E continua o autor explicando:

Se encararmos o tema em face dos caracteres gerais do constitucionalismo e do Verfassungsstaat, as duas tendências não se afastam realmente muito uma da outra: os 'contrapesos' freiam os excessos governamentais em sentido equivalente ao da limitação recíproca que a 'separação' francesa oferece. Trata-se de não permitir nem a invasão de atribuições nem o seu enfeixamento numa só mão ('ai da infeliz vítima - dizia um personagem do Maria Stuart de Schiller - se a mesma boca que dita a lei profere a sentença'), embora o primeiro ponto, o do impedimento às invasões recíprocas, se achasse mais nítido nos enunciados franceses. A este respeito, aliás, são muito valiosas as explanações do Prof. M. J. C. Vile, no seu livro sobre o constitucionalismo e a separação dos poderes.

Por certo, contrapondo-se à concepção francesa temos a concepção americana (mas não apenas americana ${ }^{57}$ ) do checks and balances, inspirada não na ideologia da

\footnotetext{
54 “A constituição inglesa revelaria uma fraqueza então particularmente notória: a susceptibilidade de ser subvertida por um chefe do executivo aspirando a plenos poderes e não hesitando em dominar o legislativo. A única forma de impedir a subversão consistiria em manter os vários órgãos institucionais em equilíbrio, basicamente através da manutenção da sua separação (independência) uns dos outros e da atribuição a cada um de meios de recíproco controle”. PIÇARRA, Nuno. A Separação dos Poderes como Doutrina e Princípio Constitucional. Um contributo para o estudo das suas origens e evolução. Coimbra: Coimbra Editora Limitada, 1989, p. 85.

${ }^{55}$ LIMA, Fernando Machado da Silva. Jurisdição Constitucional e Controle do Poder. Porto Alegre: Sérgio Antônio Fabris Ed., 2005, p. 39.

${ }^{56}$ SALDANHA, Nélson. O Estado Moderno e a Separação de Poderes. São Paulo: Saraiva, 1987, p. 115.

57 “Como na nomeação dos juízes da Supreme Court americana, assim também na nomeação dos juízes das Cortes Constitucionais européias há uma intervenção do poder legislativo ou executivo, pelo que, sob este último aspecto, pode-se reconhecer, também nas vigentes Constituições austríaca, italiana e alemã, antes uma parcial aceitação do sistema dos checks and balances, que daquele montesquiano da nítida separação
} 
nítida separação, mas na do recíproco controle e equilíbrio dos poderes do Estado, o que permite explicar como o Judiciário pode, na América, controlar a legitimidade constitucional das leis e dos atos administrativos, e como o Legislativo e o Executivo podem intervir quando da escolha e da nomeação dos juízes da Supreme Court. Então, enquanto no sistema francês há um controle não judicial, mas meramente político e preventivo de constitucionalidade das leis, no sistema americano há o controle judicial e difuso (judicial review) ${ }^{58}$.

Em dois pontos, os mais estratégicos e delicados da organização política inglesa, o Barão de La Brède se afastou da teoria dos checks and balances. Quais sejam: primeiro, quando na separação dos poderes, referidos poderes deveriam estar separados funcionalmente (cada órgão com sua função especializada), bem como esses poderes deveriam estar separados organicamente (órgãos com independência recíproca, em pé de igualdade). Estas separações (funcionais e orgânicas) acabariam por resultar numa política com liberdade. Segundo, também se afastou da teoria dos checks and balances uma vez que não há uma hierarquização entre os poderes, e esta igualdade entre eles (fruto da separação orgânica) levou Montesquieu a omitir um poder e uma função capaz de, em atos, representar a unidade do Estado, e exercer a prerrogativa de um poder discricionário focado no bem comum mais elevado quando se fizesse necessário um agir político extremado de última instância ${ }^{59}$.

Na Inglaterra os órgãos políticos estavam separados (Rei, Casas Legislativas e Altas Cortes), mas trabalhavam juntos no mesmo e único espaço institucional, qual seja, o Parlamento; isto é, os três poderes ingleses eram órgãos de uma só instituição, o Parlamento, dividindo, portanto, a mesma soberania. No sistema dos checks and balances, a cooperação entre os poderes era decorrência não só do ambiente favorável que eles dividiam, como, também, dos virtuais constrangimentos da instituição unificante e envolvente sobre cada um dos poderes individualmente. Na Inglaterra há, sim, uma hierarquia formal e virtual entre os órgãos, e o Rei inglês tem o poder de presentar a unidade do Estado, bem como a prerrogativa de tomar, em última instância, a decisão significativa, quando em defesa da liberdade.

Lembra Nuno Piçarra ${ }^{60}$ que "são bem conhecidas quer a função inequivocamente criadora e constitutiva de Direito dos juízes ingleses, quer a sua margem de autonomia decisória, no quadro do sistema de precedentes do common law”.

Para Montesquieu, a liberdade seria o suficiente, bem como a autoridade seria desnecessária e inconveniente. A liberdade dos poderes, no modelo francês, limitada apenas pela liberdade do outro órgão que é igual a sua, deveria ter o poder de criar um movimento natural das coisas, uma mão invisível, que possibilitasse, por si só,

dos poderes do Estado”. CAPPELLETTI, Mauro. O Controle Judicial de Constitucionalidade das Leis no Direito Comparado. Trad. Aroldo Plínio Gonçalves. Porto Alegre: Sérgio Antônio Fabris Editor, 1984, p. 100.

${ }^{58}$ CAPPELLETTI, Mauro. O Controle Judicial de Constitucionalidade das Leis no Direito Comparado. Trad. Aroldo Plínio Gonçalves. Porto Alegre: Sérgio Antônio Fabris Editor, 1984, p. 98-99.

${ }^{59}$ SOUZA JÚNIOR, Cezar Saldanha. O Tribunal Constitucional como Poder. Uma nova teoria da divisão dos poderes. São Paulo: Memória Jurídica, 2002, p. 58-59.

${ }^{60}$ PIÇARRA, Nuno. A Separação dos Poderes como Doutrina e Princípio Constitucional. Um contributo para o estudo das suas origens e evolução. Coimbra: Coimbra Editora Limitada, 1989, p. 97. 
independentemente de qualquer outro poder superior, a garantia da liberdade, da harmonia e da concórdia ${ }^{61}$.

Ressalta-se, no entanto, que não só as instituições inglesas influenciaram os americanos, como também a idéia de Montesquieu os influenciou, e o impacto do progresso da civilização norte-americana pelo mundo ajudou a difundir as idéias do Barão. A expressão “governo dos juízes” não é considerada absurda nos Estados Unidos da América, onde os juízes têm um papel político implícito na organização constitucional dos Poderes, e onde o alcance do Judiciário é tão significativo que se pode falar em "revolução constitucional” promovida pelos juízes ${ }^{62}$.

Foi a ideia da tripartição de poderes $^{63}$ recriada por Montesquieu que permitiu a independência dos juízes frente ao Poder Executivo e Legislativo, uma vez que possibilitou a supremacia do Direito sobre o público, criando, assim, o Estado de Direito $^{64}$. Portanto, a grande contribuição de Montesquieu à modernidade foi a viabilização da supremacia do Direito sobre o público ${ }^{65}$.

Bem lembra Dallari ${ }^{66}$, que por motivos que têm raízes na história, a Inglaterra nunca teve o Judiciário como um poder independente na organização do Estado, por isso para os ingleses não faz sentido falar em Poder Judiciário, muito menos em poder político dos juízes, pois estes são subordinados ao Parlamento. O ofício dos juízes ingleses é jus dicere e não jus dare, ou seja, interpretar a lei e não fazer ou dar a lei. O juiz não é legislador, como também não é um autômato, um aplicador cego da lei, tendo, sim, que interpretá-la. Na França ${ }^{67}$ a situação é um pouco diferente, mas da mesma

${ }^{61}$ SOUZA JÚNIOR, Cezar Saldanha. O Tribunal Constitucional como Poder. Uma nova teoria da divisão dos poderes. São Paulo: Memória Jurídica, 2002, p. 60.

${ }^{62}$ DALLARI, Dalmo de Abreu. O Poder dos Juízes. São Paulo: Saraiva, 2002, p. 93.

63 Sobre as idéias de bipartição, tetrapartição, pentapartição e hexapartição dos poderes - SOUZA JÚNIOR, Cezar Saldanha. O Tribunal Constitucional como Poder. Uma nova teoria da divisão dos poderes. São Paulo: Memória Jurídica, 2002.

${ }^{64}$ A efetivação do Estado de Direito necessitou, ainda, de mais duas invenções: um novo ramo do direito, que é o direito constitucional; além do controle jurisdicional da administração e do controle de constitucionalidade das leis. SOUZA JÚNIOR, Cezar Saldanha. O Tribunal Constitucional como Poder. Uma nova teoria da divisão dos poderes. São Paulo: Memória Jurídica, 2002, p. 62.

${ }^{65}$ Segundo Nuno Piçarra: "à luz da história da doutrina da separação dos poderes a distinção funcional entre legislação e execução mostra-se absolutamente essencial. Ela traduz, na realidade, duas formas materialmente distintas de atuação jurídica do Estado: a edição de normas gerais e abstratas, prévia e independentemente de casos concretos, que é conquista definitiva da Idade Moderna e componente essencial do Estado de Direito. Tal distinção não pretendia originariamente abarcar a totalidade das funções estaduais, embora tenha vindo posteriormente a pretendê-lo num modelo de Estado que, como o liberal, se concebia, mais do que limitado pelo Direito, limitado ao Direito e, por isso, reduzido a um esquema simples: leis por um lado, tribunais e força pública por outro, destinados a assegurar o cumprimento delas. (...) Também é palpável a pretensão de, no trinômio legislativo, executivo e judicial, fazer caber exaustivamente a totalidade das funções estaduais, de natureza integralmente jurídica e não política. (...) As funções estaduais parecem, pois, resumir-se à edição de leis e à sua execução pela força pública, diretamente ou mediante a intervenção dos tribunais” PIÇARRA, Nuno. A Separação dos Poderes como Doutrina e Princípio Constitucional. Um contributo para o estudo das suas origens e evolução. Coimbra: Coimbra Editora Limitada, 1989, p. 92-93.

${ }^{66}$ DALLARI, Dalmo de Abreu. O Poder dos Juízes. São Paulo: Saraiva, 2002, p. 90.

${ }^{67} \mathrm{O}$ texto constitucional da atual Constituição da França de 1958 não fala em poderes, traz o Presidente da República, o Governo, o Parlamento e fala em “autoridade judiciária”, dispondo que esta última será garantida 
forma há muita resistência à concessão de grandes poderes aos juízes, bem como resistência à interferência destes na política.

Nuno Piçarra ${ }^{68}$ enfatiza que:

Em matéria de separação dos poderes, tanto em sentido orgânicofuncional como em sentido político-social, Montesquieu terá dito pouco, ou mesmo nada, de verdadeiramente original relativamente às doutrinas jurídicas e políticas da Inglaterra do tempo. Mas deu certamente o impulso decisivo para transformar a doutrina da separação dos poderes, de doutrina inglesa, em critério do Estado constitucional. Não sem equívocos, anacronismos e incompreensões posteriores, dado que na sua versão coexistem idéias já definitivamente pertencentes ao passado e idéias destinadas a perdurar no futuro. Ao longo dos dois séculos seguintes, tanto haveria de ser rejeitada como aclamada em nome daquilo que hoje é traço jurídico-político comum do Ocidente: o Estado democráticorepresentativo, em que a conciliação do pluralismo de poder com a 'constituição permanente da unidade política' continua a ser, tal como para Montesquieu, questão essencial.

Para terminar esta pesquisa nos valemos, mais uma vez, das palavras do Barão de La Brède ${ }^{69}$ :

Desejaria ter pesquisado, em todos os governos moderados que conhecemos, qual a distribuição dos três poderes, e daí calcular o grau de liberdade dos quais cada um deles pode gozar. Entretanto, nem sempre se deve deixar que se esgote o assunto a ponto de nada deixar para que o leitor também se esforce. Não se trata aqui de fazer ler, mas de fazer pensar.

\section{CONSIDERAÇÕES FINAIS}

Mister que a idéia de Montesquieu acerca da teoria da separação dos poderes, ainda que não tenha sido a precursora, tenha ficado clara: dividir o poder entre três órgãos, cada qual com sua função, sem hierarquização entre eles. Também imprescindível que a noção dos checks and balances mostre as suas diferenças para com a recém referida teoria: não há nítida separação de poderes mas, sim, recíproco controle e equilíbrio dos poderes, havendo a hierarquização tão combatida pelo Barão de La Brède.

O certo é que o tema não foi exaurido, porque, como diz Montesquieu, o assunto não pode se esgotar para que o leitor também tenha o que continuar buscando.

pelo Presidente da República, para que ela possa assegurar as liberdades essenciais, devendo uma lei orgânica fixar o estatuto dos magistrados. Portanto, a Constituição Francesa não fala em Poder Judiciário, muito menos os juízes recebem competências que possibilitem a interferência no exercício do poder político. DALLARI, Dalmo de Abreu. O Poder dos Juízes. São Paulo: Saraiva, 2002, p. 92.

${ }^{68}$ PIÇARRA, Nuno. A Separação dos Poderes como Doutrina e Princípio Constitucional. Um contributo para o estudo das suas origens e evolução. Coimbra: Coimbra Editora Limitada, 1989, p. 122-123.

${ }^{69}$ MONTESQUIEU, Charles Louis de Sécondat, baron de la Brède et de. Do Espírito das Leis. Trad. Jean Melville. São Paulo: Editora Martin Claret, 2004, p. 195. 


\section{REFERÊNCIAS}

BACHOF, Otto. Jueces y Constitución. Trad. Rodrigo Bercovitz Rodriguéz-Cano. Madrid: Civitas, 1987.

BASTOS, Celso Ribeiro. Curso de Teoria do Estado e Ciência Política. São Paulo: Saraiva, 1999.

BITAR, Orlando Chicre Miguel. A Lei e a Constituição. Alguns Aspectos do Controle Jurisdicional de Constitucionalidade, in Obras Completas de Orlando Bitar. Rio de Janeiro: Renovar, vol. I, 1996.

BOBBIO, Norberto. Direito e Estado no Pensamento de Emanuel Kant. Trad. Alfredo Fait. Brasília: Editora Universidade de Brasília, 1997.

CAETANO, Marcelo. Manual de Ciência Política e Direito Constitucional. Lisboa: Coimbra Ed. 1963.

CALLEJON, Maria Luisa Balaguer. La interpretación de la Constitución por la Jurisdicción Ordinária. Madrid: Civitas, 1990.

CAMPILONGO, Celso Fernandes. Direito e Democracia. São Paulo: Max Limonad, s.d.

CAPPELLETTI, Mauro. O Controle Judicial de Constitucionalidade das Leis no Direito Comparado. Trad. Aroldo Plínio Gonçalves. Porto Alegre: Sérgio Antônio Fabris Editor, 1984.

CANOTILHO, José Joaquim Gomes. Direito Constitucional. Coimbra: Almedina, s.d.

CINTRA, Geraldo de Ulhoa. Da Jurisdição. Rio de Janeiro: Lux Editora, 1958.

COMPARATO, Fábio Konder. Réquiem para uma Constituição. In: O Desmonte da Nação. Petrópolis: Vozes, 1999.

DALLARI, Dalmo de Abreu. O Poder dos Juízes. São Paulo: Saraiva, 2002.

FACCHINI NETO, Eugênio. O juiz não é só de Direito. In ZIMERMAN, David; COLTRO, Antônio Carlos Mathias. Aspectos psicológicos na prática jurídica. Campinas: Millennium, 2002.

FARIA, José Eduardo. Eficácia Jurídica e Violência Simbólica - O Direito como instrumento de formação social. São Paulo: EDUSP, Série Pensamento Jurídico - Teses, 1998.

FERRAJOLI, Luigi. Direito e Razão. Teoria do Garantismo Penal. São Paulo: Editora Revista dos Tribunais, 2002.

FERRAZ JÚNIOR, Tércio Sampaio. Introdução ao Estudo do Direito: Técnica, Decisão, Dominação. São Paulo: Atlas, 1994.

FRIEDRICH, Carl. Gobierno Gonstituiconal y Democracia. Madrid: Instituto de Estúdios Políticos, 1975.

GUARNIERI, Carlo. Magistratura e Política in Itália. Bologna: Societá Editrice il Mulino/ Contemporânea 55, 1992, 1993.

GUIMARÃES, Mário. O Juiz e a Função Jurisdicional. Rio de Janeiro: Forense, 1958.

HESSE, Konrad. A Força Normativa da Constituição. Trad. Gilmar Ferreira Mendes. Porto Alegre: Sérgio Antônio Fabris Editor, 1991.

IHERING, Rudolph Von. A luta pelo Direito. São Paulo: Editora RT, 2. ed., 2001.

KELSEN, Hans. A Democracia. São Paulo: Martins Fontes, 1993. Jurisdição Constitucional. São Paulo: Martins Fontes, 2003.

LAFER, Celso. A Reconstrução dos Direitos Humanos. Um diálogo com o pensamento de Hannah Arendt. São Paulo: Companhia das Letras, 1988.

LASSALE, Ferdinand. O que é uma Constituição? Belo Horizonte: Editora Líder, 2001.

LEBRUN, Gerard. O que é Poder. São Paulo: Editora Brasiliense, 1984.

DIREITOS FundAMENTAIS E E JUSTIÇA N' 8 - JUL./SET. 2009 
LIMA, Fernando Machado da Silva. Jurisdição Constitucional e Controle do Poder. É efetiva a Constituição Brasileira? Porto Alegre: Sérgio Antônio Fabris Editor, 2005.

LOEWENSTEIN, Karl. Teoria de la Constitución. Trad. Alfredo Gallego Anabitarte. Barcelona: Ed. Ariel, 1970.

MADISON, James; HAMILTON, Alexander; JAY, John. O Federalista - Um comentário à Constituição Americana. Trad. Reggy Zacconi de Moraes. Rio de Janeiro: Editora Nacional de Direito, 1959.

MAGALHÃES, José Luiz Quadros de. Democracia e crise: alternativas estruturais para o Brasil. In: Jus Navegandi, n.58. [Internet] http://www.jus.com.br/doutrina/texto.asp?id=3157

MONTESQUIEU, Charles Louis de Sécondat, baron de la Brède et de. Do Espírito das Leis. Trad. Jean Melville. São Paulo: Editora Martin Claret, 2004.

MORAES, Alexandre de. Jurisdição Constitucional e Tribunais Constitucionais. Garantia Suprema da Constituição. São Paulo: Atlas, 2000.

MOREIRA NETO, Diogo de Figueiredo. O Sistema Judiciário Brasileiro e a Reforma do Estado. São Paulo: Celso Bastos Editor/Instituto Brasileiro de Direito Constitucional, 1999.

OLIVEIRA, Alexandre Nery de. A Reforma do Judiciário - IV, disponível na internet em http://usr.solar.com.br/ anery

OLIVEIRA, Rodrigo Valin de. O Poder Moderador. Tese apresentada ao Curso de Doutorado da Faculdade de Direito da Universidade de São Paulo. Orientador: Manoel Gonçalves Ferreira Filho. São Paulo: 2003.

PIÇARRA, Nuno. A Separação dos Poderes como Doutrina e Princípio Constitucional. Um contributo para o estudo das suas origens e evolução. Coimbra: Coimbra Editora Limitada, 1989. RADBRUCH, Gustav. Filosofia do Direito. São Paulo: Martins Fontes, 2004.

ROCHA, Carmem Lúcia Antunes. Democracia, Constituição e Administração Pública, in Boletim de Direito Administrativo, n. 9, 1999.

SALDANHA, Nélson. O Estado Moderno e a Separação de Poderes. São Paulo: Saraiva, 1987. SCHWARTZ, Bernard. Direito Constitucional Americano. Rio de Janeiro: Forense, 1955.

SILVA, José Afonso da. Processo Constitucional de Formação das Leis. São Paulo: Malheiros Editores, 2006.

SOUZA JÚNIOR, Cezar Saldanha. O Tribunal Constitucional como Poder. Uma nova teoria da divisão dos poderes. São Paulo: Memória Jurídica, 2002.

TAVARES, André Ramos. Curso de Direito Constitucional. São Paulo: Saraiva, 2003.

A Superação da Doutrina Tripartite dos 'Poderes' do Estado. Cadernos de Direito Constitucional e Ciência Política, v. 29, out./dez.1999, ano 7, p. 66-71.

TAVARES FILHO, Newton. Procedimento de Escolha e Nomeação dos Titulares de Cortes Constitucionais no Direito Comparado. Disponível na internet em: http://www.camara.gov.br/internet/diretoria/Conleg/Estudos/ 204689.pdf.

TEMER, Michel. Elementos de Direito Constitucional. São Paulo: Malheiros, 2000.

TESHEINER, José Maria Rosa. A Reforma do Judiciário, disponível na internet em: http://www.tex.pro.br/wwwroot/artigosprofessortesheiner/reformadojudiciario.htm

TOCQUEVILLE, Aléxis. Democracy in América, Part II, Book IV. Disponível em: http://xroads.virginia.edu/ HYPER/DETOC/toc_index.html.

VELLOSO, Carlos Mário da Silva. Problemas e Soluções na Prestação da Justiça, In: TEIXEIRA, Sálvio de Figueiredo (Coord.). O Judiciário e a Constituição. São Paulo: Saraiva, 1994. 